www.jmscr.igmpublication.org

Index Copernicus Value: 79.54

ISSN (e)-2347-176x ISSN (p) 2455-0450

crossref DOI: https://dx.doi.org/10.18535/jmscr/v7i3.209

\title{
Assessment of Knowledge about Infections due to Unhygienic Practice during Menstruation among the School going girls - A Statistical Approach
}

\author{
Authors \\ Mrs. Trupti Saket Bhosale, Satish V. Kakade, Mr. Sagar B. Bhosale \\ KIMSDU Karad
}

\begin{abstract}
Need of the study: Menstruation is a natural part of women's reproductive cycle. Most of the time schools going girls are unaware - in terms of knowledge, practices and attitudes for handling the menstrual cycle.

Hence the data obtained are beneficial for planning a program for improving the knowledge about infection rate due to unhygienic practice, awareness and hygienic practices during menstruation for promoting quality of life in school going girls.

Objectives: The objectives of this study were

1. To assess the knowledge and infection rate of school going girls regarding menstrual hygiene.

2. To find association between knowledge and infection rate with selected socio demographic variables. Material \& Methods: Used for the study is the evaluative approach with only study group. Study was conducted on 60 school going girls using convenient sampling technique. The data were collected by structured questionnaire. The data were analyzed using descriptive and inferential statistics.

Results: Majority of adolescent girls 32(53.3\%) had average level of knowledge about infection rate due to unhygienic practice during menstruation whereas 27(45\%) of school going girls had good level of knowledge regarding infection rate. Only 1 subject 1(1.7\%) had poor knowledge. Also, majority of school going girls 52(86.7\%) had moderate infection rate due to unhygienic practice during menstruation whereas $8(13.3 \%)$ of girls had low infection rate.

Conclusion: It was found that; planned teaching program's will be effective in increasing the knowledge of adolescent girls regarding infections rate due to unhygienic practice during menstruation. Girls should be made aware about the process of menstruation and importance of maintaining its hygiene before stepping menarche. A physically and mentally healthy adolescent girl can become a healthy adult female in her future life.

Keywords: Menstruation, Infection rate, adolescent girls, unhygienic practice.
\end{abstract}

\section{Introduction}

Menstruation is a natural part of women's reproductive cycle. Cultural practices and taboos around menstruation impact negatively the lives of adolescent girls and women, and also strengthen gender inequities and exclusion. ${ }^{1}$ Adolescent girls constitute a vulnerable group, particularly in India where female child is neglected as indicated by sex ratio. Menstruation, though natural process, still regarded as something unclean or dirty in Indian society and linked with several misbelieve and practices which results in unfavorable health outcomes. Moreover, studies have proved a direct link between poor menstrual 
hygiene and urinary or reproductive tract infections and other illnesses. $^{2}$

Women and girls of reproductive age need access to clean and soft absorbent sanitary products and practice of cleaning of genital area during menstruation. Poor personal hygiene during menses, use of unclean napkins or cloth napkins results in retaining of micro -organisms causing reproductive and urinary tract infections. Menstrual hygiene and management is an issue that is insufficiently acknowledged and has not received adequate attention. Very few studies have included the aspects of menstrual practices prevalent among young girls ${ }^{3,4}$.

Good hygienic practices such as the use of sanitary pads and adequate washing of the genital area are essential during menstruation. Women and girls of the reproductive age need access to clean and soft, absorbent sanitary products which can, protect their health. ${ }^{5}$

Poor MHM may increase a woman's sensitivity to reproductive tract infections (RTI).

Hygiene-related practices of girls and women during menstruation are of much importance, as it has a health impact in terms of increased vulnerability to Reproductive Tract Infections (RTI).

Most of the time adolescent girls are unaware - in terms of knowledge, practices and attitudes - for handling the menstrual cycle. ${ }^{6}$ It was therefore considered as important to investigate the menstruation hygiene practices and utilization of health care services by adolescent girls. The data obtained are beneficial for planning a program for improving the knowledge about infection rate due to unhygienic practice, awareness and hygienic practices during menstruation for promoting quality of life in school going girls.

\section{Materials and Methods}

The evaluative approach with one group design was used. Study was conducted on sample of 60 school going girls by using convenient sampling technique.

\section{Statistical Methods}

Data were collected, tabulated and analyzed using SPSS version 20.0 with regard to objectives of the study using descriptive and Inferential Statistics. Descriptive Statistics namely frequency and percentage was done. Chi square test was used to check the association between selected demographic variables and knowledge and infection rate of school going girls.

\section{Results}

Table 1: Frequency and Percentage distribution of school going girls according to socio demographic parameters

$\mathrm{N}=60$

\begin{tabular}{|l|c|c|c|}
\hline Sr. No. & Demographic Variables & Frequency & Percent \\
\hline \multirow{4}{*}{} & \multicolumn{3}{|c|}{ Age groups } \\
\cline { 2 - 4 } & $11-12$ & 34 & 56.7 \\
\cline { 2 - 4 } & $12-13$ & 26 & 43.3 \\
\hline \multirow{4}{*}{} & \multicolumn{3}{|c|}{ Education } \\
\cline { 2 - 4 } & 6th standard & 26 & 43.3 \\
\cline { 2 - 4 } & 7th standard & 34 & 56.7 \\
\cline { 2 - 4 } & 8th standard & 30 & 50.0 \\
\hline \multirow{4}{*}{3} & Urban Residence \\
\cline { 2 - 4 } & Rural Income \\
\hline 4 & \multicolumn{3}{|c|}{30.0} \\
\cline { 2 - 4 } & Rs. 10,000/- & 30 & 50.0 \\
\cline { 2 - 4 } & Above Rs. 10000/- & 30 & 50.0 \\
\hline 5 & Source of Information \\
\cline { 2 - 4 } & Teachers & 16 & 26.7 \\
\cline { 2 - 4 } & Mother & 41 & 68.3 \\
\cline { 2 - 4 } & Others & 3 \\
\hline
\end{tabular}

Table 2 Distributions of school going girls according to level of knowledge

$\mathrm{N}=60$

\begin{tabular}{|l|c|c|c|}
\hline $\begin{array}{l}\text { Level of } \\
\text { Knowledge }\end{array}$ & Score & Frequency & Percent \\
\hline Poor & $0-4$ & 01 & 1.7 \\
\hline Average & $5-9$ & 32 & 53.3 \\
\hline Good & $10-13$ & 27 & 45.0 \\
\hline \multicolumn{2}{|c|}{ Total } & 60 & 100 \\
\hline
\end{tabular}

The table-2 shows the level of knowledge of school going girls regarding infections due to unhygienic practice during menstruation. In the table it is noticeable that majority of adolescent girls $32(53.3 \%)$ had average level of knowledge about infection rate due to unhygienic practice during menstruation whereas $27(45 \%)$ of school going girls had good level of knowledge regarding 
infection rate. Only 1 subject $1(1.7 \%)$ had poor knowledge.

Table- 3: Distribution of school going girls according to level of reproductive tract infection rate

\begin{tabular}{|l|c|c|c|}
\hline $\begin{array}{l}\text { Level of Infection } \\
\text { Rate }\end{array}$ & Score & Frequency & Percent \\
\hline Low & $1-3$ & 8 & 13.3 \\
\hline Moderate & $4-6$ & 52 & 86.7 \\
\hline \multicolumn{2}{|c|}{ Total } & 60 & 100 \\
\hline
\end{tabular}

The above table- 3 shows the level of infection rate of school going girls due to unhygienic practice during menstruation. In the table it is noticeable that majority of school going girls 52(86.7\%) had moderate infection rate due to unhygienic practice during menstruation whereas $8(13.3 \%)$ of girls had low infection rate.

Table-4: Association between demographic variables and level of knowledge about infection rate due to unhygienic practice during menstruation of school going girls

$\mathrm{N}=60$

\begin{tabular}{|c|c|c|c|c|c|c|c|c|c|c|}
\hline \multirow{3}{*}{ Sr. No. } & \multirow{3}{*}{ Demographic Variables } & \multicolumn{6}{|c|}{ Levels of Knowledge } & \multirow{3}{*}{ Total } & \multirow{3}{*}{$\begin{array}{l}\text { Chi Square } \\
\text { Statistic }\end{array}$} & \multirow{3}{*}{ p value } \\
\hline & & \multicolumn{2}{|c|}{ Poor } & \multicolumn{2}{|c|}{ Average } & \multicolumn{2}{|c|}{ Good } & & & \\
\hline & & $\mathbf{F}$ & $\%$ & $\mathbf{F}$ & $\%$ & $\mathbf{F}$ & $\%$ & & & \\
\hline \multirow{3}{*}{1} & Age groups & & & & & & & & & \\
\hline & $11-12$ & 1 & 2.94 & 16 & 47.06 & 17 & 50.00 & 34 & \multirow[b]{2}{*}{1} & \multirow{2}{*}{0.61} \\
\hline & $12-13$ & 0 & 0.00 & 15 & 57.69 & 11 & 42.31 & 26 & & \\
\hline \multirow{3}{*}{2} & Education & & & & & & & & & \\
\hline & 7th standard & 1 & 3.85 & 17 & 65.38 & 8 & 30.77 & 26 & \multirow{2}{*}{4.62} & \multirow{2}{*}{0.09} \\
\hline & 8th standard & 0 & 0.00 & 15 & 44.12 & 19 & 55.88 & 34 & & \\
\hline \multirow{3}{*}{3} & Residence & & & & & & & & & \\
\hline & Urban & 0 & 0.00 & 18 & 60.00 & 12 & 40.00 & 30 & \multirow{2}{*}{1.83} & \multirow{2}{*}{0.4} \\
\hline & Rural & 1 & 3.33 & 14 & 46.67 & 15 & 50.00 & 30 & & \\
\hline \multirow{3}{*}{4} & Income & & & & & & & & & \\
\hline & $<$ Rs. $10000 /-$ & 1 & 3.33 & 15 & 50.00 & 14 & 46.67 & 30 & \multirow{2}{*}{1.16} & \multirow{2}{*}{0.56} \\
\hline & Above Rs. 10000/- & 0 & 0.00 & 13 & 43.33 & 17 & 56.67 & 30 & & \\
\hline \multirow{4}{*}{5} & Source of Information & & & & & & & & & \\
\hline & Teachers & 0 & 0.00 & 13 & 81.25 & 3 & 18.75 & 16 & \multirow{3}{*}{9.59} & \multirow{3}{*}{$0.04 *$} \\
\hline & Mother & 1 & 2.44 & 19 & 46.34 & 21 & 51.22 & 41 & & \\
\hline & Others & 0 & 0.00 & 0 & 0.00 & 3 & 100.00 & 3 & & \\
\hline
\end{tabular}

F: Frequency, \%: Percentage, *: Significant

Table-4 shows the association of knowledge level of school going girls about infection rate due to unhygienic practice during menstruation with their selected demographical variables. It was done using Chi -square test. The analysis revealed that, there was significant association for source of information with level of knowledge. No. of school going girls having average and good knowledge received from mothers were significantly higher than that of school going girls having average and good knowledge received from teachers or others.

No significant association was found for rest of the demographic variables of school going girls. 
Table 5: Association between demographic variables and reproductive tract infection rate due to unhygienic practice during menstruation of school going girls

$\mathrm{N}=60$

\begin{tabular}{|c|c|c|c|c|c|c|c|c|}
\hline \multirow{3}{*}{ Sr. No. } & \multirow{3}{*}{ Demographic Variables } & \multicolumn{4}{|c|}{ Levels of Infection Rate } & \multirow{3}{*}{ Total } & \multirow{3}{*}{$\begin{array}{c}\text { Chi } \\
\text { Square } \\
\text { Statistic }\end{array}$} & \multirow{3}{*}{ p value } \\
\hline & & \multicolumn{2}{|c|}{ Low } & \multicolumn{2}{|c|}{ Moderate } & & & \\
\hline & & $\mathbf{F}$ & $\%$ & $\mathbf{F}$ & $\%$ & & & \\
\hline \multirow{3}{*}{1} & Age groups & & & & & & & \\
\hline & $11-12$ & 1 & 2.94 & 33 & 97.06 & 34 & \multirow{2}{*}{7.33} & \multirow{2}{*}{$0.007 *$} \\
\hline & $12-13$ & 7 & 26.92 & 19 & 73.08 & 26 & & \\
\hline \multirow{3}{*}{2} & Education & & & & & & & \\
\hline & 7th standard & 1 & 3.85 & 25 & 96.15 & 26 & \multirow{2}{*}{3.57} & \multirow{2}{*}{$0.05^{*}$} \\
\hline & 8th standard & 7 & 20.59 & 27 & 79.41 & 34 & & \\
\hline \multirow{3}{*}{3} & Residence & & & & & & & \\
\hline & Urban & 5 & 16.67 & 25 & 83.33 & 30 & \multirow{2}{*}{0.58} & \multirow{2}{*}{0.45} \\
\hline & Rural & 3 & 10.00 & 27 & 90.00 & 30 & & \\
\hline \multirow{3}{*}{4} & Income & & & & & & & \\
\hline & < Rs. $10000 /-$ & 5 & 16.67 & 25 & 83.33 & 30 & \multirow{2}{*}{0.58} & \multirow{2}{*}{0.45} \\
\hline & Above Rs. 10000/- & 3 & 10.00 & 27 & 90.00 & 30 & & \\
\hline \multirow{4}{*}{5} & Source of Information & & & & & & & \\
\hline & Teachers & 3 & 18.75 & 13 & 81.25 & 16 & \multirow{3}{*}{1.89} & \multirow{3}{*}{0.88} \\
\hline & Mother & 4 & 9.76 & 37 & 90.24 & 41 & & \\
\hline & Others & 1 & 33.33 & 2 & 66.67 & 3 & & \\
\hline
\end{tabular}

F: Frequency, \%: Percentage, *: Significant

Table-5 shows the association of reproductive tract infection rate of school going girls due to unhygienic practice during menstruation with their selected demographical variables. It was done using Chi -square test. The analysis revealed that, there was significant association for age groups and education with infection rate. No. of school going girls having moderate infection rate were significantly higher for both the age groups and no. of school going girls having moderate infection rate were border line significantly higher in both standards.

No significant association was found for rest of the demographic variables of school going girls.

\section{Discussion}

Some research studies have been conducted in National and International level to assess knowledge about infections due to unhygienic practice during menstruation among the school going girls.

In our study, $85 \%$ girls had history of regular menstrual cycle. Similar finding have also been reported by Mohite RV as $75.2 \%$.
This study depicted the proportion of practices of disposable adsorbent sanitary napkins and household non-disposable; non-adsorbent cloth (linen) materials among girls were 94\% and 6\% respectively. Different finding has also been reported from Baridalyne and Reddaiah ${ }^{9}$, as less than of one-third of the study girls used sanitary absorbents pads. This indicates that the awareness about menstrual hygiene is quiet good than previous which could be due to literacy, positive attitude of community as well as start of establishment of health care services.

In our study, 95\% girls reported that they are taking daily bath during menstruation. Similar finding have also been reported by Mohite $\mathrm{RV}^{7}$ as, the practices of personal hygiene including bath during menstruation and cleaning of external genital parts were followed by $95.2 \%$ girls respectively. However, Bhattacherjee observed, less than one third of girls were practiced good personal hygiene ${ }^{11}$.

The study showed, 5\% girls practiced an insanitary method of disposal of materials whereas Mohite $\mathrm{RV}^{7}$ observed little higher proportion i.e. $77.3 \%$ girls were practiced 
improper method of disposal of material used during menstruation. This difference in reports could be due to poverty, illiteracy both in girls as well mothers, poor awareness, dominance of cultural, religious and traditional practices, poor access of services from public as well as private sector.

The study showed, $85 \%$ girls they visit to PHC if they have genito urinary tract infection. Mohite $\mathrm{RV}{ }^{7}$ study revealed, $14.3 \%$ adolescent girls from slum area were utilized health care services for menstruation related problems and of which, $51.5 \%$ followed private health care services.

\section{Conclusion}

From the data analysis and findings of the present study, it is concluded that majority of adolescent girls $32(53.3 \%)$ had average level of knowledge about infection rate due to unhygienic practice during menstruation whereas $27(45 \%)$ of school going girls had good level of knowledge regarding infection rate. Only 1 subject $1(1.7 \%)$ had poor knowledge

Also, majority of school going girls 52(86.7\%) had moderate infection rate due to unhygienic practice during menstruation whereas $8(13.3 \%)$ of girls had low infection rate.

There was significant association for source of information with level of knowledge. No. of school going girls having average and good knowledge received from mothers were significantly higher than that of school going girls having average and good knowledge received from teachers or others. No significant association was found for rest of the demographic variables of school going girls.

There was significant association for age groups and education with infection rate. No. of school going girls having moderate infection rate were significantly higher for both the age groups and no. of adolescent girls having moderate infection rate were border line significantly higher in both standards. No significant association was found for rest of the demographic variables of school going girls.
Girls should be made aware about the process of menstruation and importance of maintaining its hygiene before stepping menarche. A physically and mentally healthy adolescent girl can become a healthy adult female in her future life.

\section{References}

1. Deo DS, Ghattargi CH. Perceptions and practices regarding menstruation; acomparative study in rural and urban adolescent girls. Indian J Community Med. 2005;30;33-4.

2. Khanna A, Goyal RS, Bhawsar R. Menstrual practices and reproductive problems: a study of adolescent girls in rajasthan. J Health Manag. 2005;7;91-107.

3. El-Gilany AH, Badawi K. Menstrual Hygeine among adolescent school girls in Mansoura, Egypt. Reproductive Health Matters.2005;13:147-52.

4. Devi KD, Ramaiah PV. A study on menstrual hygiene among rural adolescent girls. Indian J Med Sci. 1994;48;139-43.

5. Singh AJ. The place of menstruation in the reproductive lives of women of rural north India. Indian $\mathbf{J}$ Community Medicine. 2006;31(1):10-4.

6. Juyal R, Kandpal S.D, Semwal J, Menstrual Hygiene and Reproductive Morbidity in Adolescent Girls in Dehradun, India, Bangladesh Journal of Medical Science Vol. 13 No. 02 April'14, 170-74.

7. Mohite RV, Mohite VR. Menstrual hygiene practices among slum adolescent girls. Int J Community Med Public Health 2016;3: 1729-34.

8. Bhosale TS, Zagade T, Yedage S et.al. A study to assess the knowledge regarding the hazards of tobacco smoking among patients and relatives in selected tertiary hospital Karad. Galore International Journal of Health Sciences \& Research. 2018; 3(4): 59-63. 
9. Baridalyne N, Reddaiah VP. Menstruation: knowledge, beliefs and practices of women in the reproductive group residing in an urban resettlement colony of Delhi. Health Popul Perspect. 2004; 27:9-16.

10. Bhosale TS, Shinde M, Patel R, et al. A study to assess the quality of life after mastectomy among women in a tertiary care hospital, Karad. J. Evolution Med. Dent. Sci. 2018;7(49):6073-6077.

11. Bhattacherjee S, Roy K, Biswas R, Chakraborty M. Menstruation: experience of adolescent slum dwelling girls of siliguri city, West Bengal, India. J Basic Clin Reprod Sci. 2013; 2:85-91.

12. Trupti Bhosale, Ruksar Patel, Pavitra Patil, Rohini Yadav, A Study to Assess Effectiveness of Planned Teaching Programme on Knowledge regarding Hand washing among the Staff Nurses in Secondary Care Hospital, Karad , International Journal of Science and Research, September 2018; Vol. 7, Issue 9: 620-623. 